\title{
Desain Sistem Pendayaan Energi Listrik pada Rumah Kaca Pintar dengan Menggunakan Pembangkit Listrik Tenaga Surya
}

\author{
Levin Halim ${ }^{1}$, Christian Fredy $\mathrm{Naa}^{2}$ \\ ${ }^{1,2)}$ Teknik Elektro Universitas Katolik Parahyangan \\ Jl. Ciumbuleuit No. 94 Bandung \\ Email: ${ }^{1)}$ halimlevin@ unpar.ac.id, $^{2)}$ christian.fredy@unpar.ac.id
}

\begin{abstract}
ABSTRAK
Kecenderungan pada dewasa ini, ada berbagai masalah yang muncul pada bidang pertanian. Salah satu dari masalah tersebut yang paling utama adalah keterbatas lahan untuk ditanami. Perlu diketahui bahwa dengan peningkatan jumlah penduduk dan pembangunan, ketersediaan lahan pun menjadi berkurang secara signifikan. Rumah kaca menjadi salah satu jawaban dari masalah tersebut. Rumah kaca pada jaman ini sudah dilengkapi dengan sistem kendali dan monitoring sebagai salah satu improvement rumah kaca cerdas. Tentunya Rumah Kaca cerdas seperti demikian membutuhkan energi listrik yang handal dan berkelanjutan untuk mendapatkan fungsi rumah kaca cerdas yang baik. Penelitian ini melakukan analisis, simulasi, desain, dan implementasi nyata sistem pendayaan energi listrik untuk rumah kaca tersebut. Pendayaan energi listrik tersebut akan didayai dengan energi terbarukan yaitu energi matahari dengan teknologi PV pada Pembangkit Listrik Tenaga Surya. Sehingga dibutuhkan identifikasi beban-beban dan kebutuhan listrik yang ada pada rumah kaca, pemilihan desain sistem energi rumah kaca, penentuan spesifikasi peralatan-peralatan yang diperlukan, serta implementasi pendayaan energi listrik rumah kaca tersebut.
\end{abstract}

Kata Kunci : pembangkit listrik tenaga surya, pendayaan, energi PV, rumah kaca pintar

\section{PENDAHULUAN}

Kecenderungan pada dewasa ini, ada berbagai masalah yang muncul pada bidang pertanian. Salah satu dari masalah tersebut yang paling utama adalah keterbatas lahan untuk ditanami. Perlu diketahui bahwa dengan peningkatan jumlah penduduk dan pembangunan, ketersediaan lahan pun menjadi berkurang secara signifikan.

Indonesia merupakan salah satu negara dengan permasalahan seperti demikian, bahkan di Indonesia permasalahan keterbatasan lahan tersebut permasalahan tersebut menjadi cukup rumit karena beberapa faktor antara lain: produk lokal yang tidak memenuhi spesifikasi industri pangan, hasil produksi terbatas, perubahan selera konsumen dan perlunya mempertahankan ketersediaan produkproduk pertanian tersebut untuk menunjang kelangsungan industri-industri terkait. Selain itu, adapun permasalahan pengaruh dari globalisasi dan perkembangan teknologi pertanian menyebabkan dunia pertanian Indonesia harus segera memberikan tanggapan untuk dapat terus bersaing [1], [2].

Rumah kaca menjadi salah satu jawaban untuk menjawab permasalahan-permasalahan tersebut. Pertanian rumah kaca mempunyai banyak keuntungan, diantaranya : mudah dalam mengendalikan hama dan penyakit, bisa mengendalikan suhu dan kelembaban serta dapat lebih meningkatkan mutu produk pertanian yang dihasilkan. Meskipun demikian cara ini memerlukan biaya yang relatif lebih tinggi dan intensitas energi (energi yang digunakan per unit produksi) juga lebih besar dibandingkan dengan cara konvensional. Karena energi merupakan salah satu faktor penting, maka pengendalian sistem energi merupakan salah satu faktor untuk dapat menekan biaya produksi [3].

Pertanian rumah kaca tersebut diharapkan dapat mempunyai sistem kendali dan monitoring yang baik secara real-time. Dengan sistem kendali yang baik seperti yang dibahas pada [1], [4]-[6] diperlukan energi listrik yang cukup untuk mendayai rumah kaca tersebut. Pendayaan rumah kaca dengan energi listrik tersebut diharapkan menggunakan clean energy yang merupakan energi terbarukan tanpa menimbulkan emisi seperti yang dibahas pada [7]-[9]. Sistem pendayaan energi listrik untuk rumah kaca ini diharapkan sustainable atau berkelanjutan dan mempunyai keandalan yang cukup tinggi.

Pada penelitian yang dilakukan disini, dilakukan analisis juga implementasi nyata terhadap pendayaan energi listrik untuk pertanian rumah kaca secara mandiri, artinya pertanian rumah kaca tersebut akan memiliki sistem energi tersendiri yang lepas dari grid sehingga dapat berdiri dimanapun rumah kaca itu terbuat tanpa harus tergantung dari elektrifikasi lingkungan sekitar. Sistem pendayaan rumah kaca tersebut diharapkan mempunyai keandalan yang tinggi dan berkelanjutan dengan 
RESISTOR (elektRonika kEndali telekomunikaSI tenaga liSTrik kOmputeR) Vol. 2 No. 1 e-ISSN : 2621-9700, p-ISSN : 2654-2684

menggunakan energi terbarukan yang bebas emisi. Oleh karena itu, energi listrik yang digunakan untuk pendayaan rumah kaca ini berbasis Pembangkit Listrik Tenaga Surya (PLTS) yang memakai solar panel dengan sumber energi terbarukan cahaya matahari.

Penelitian ini akan diimplementasikan secara nyata pada rumah kaca yang dilengkapi sistem kendali dan monitoring untuk pertaniannya sebesar 2 x $3 \mathrm{~m}^{2}$. Sehingga, solar panel yang dipakai dan sistem pendayaan akan dibuat secara nyata juga untuk mendayai seluruh kebutuhan rumah kaca tersebut dengan berkelanjutan dan keandalan yang baik.

\section{METODOLOGI}

Pada penelitian ini akan dilakukan desain, analisis, serta implementasi nyata pada sistem pendayaan rumah kaca dengan tenaga PV. Sehingga berikut merupakan diagram alir untuk metode penelitian yang dilakukan:

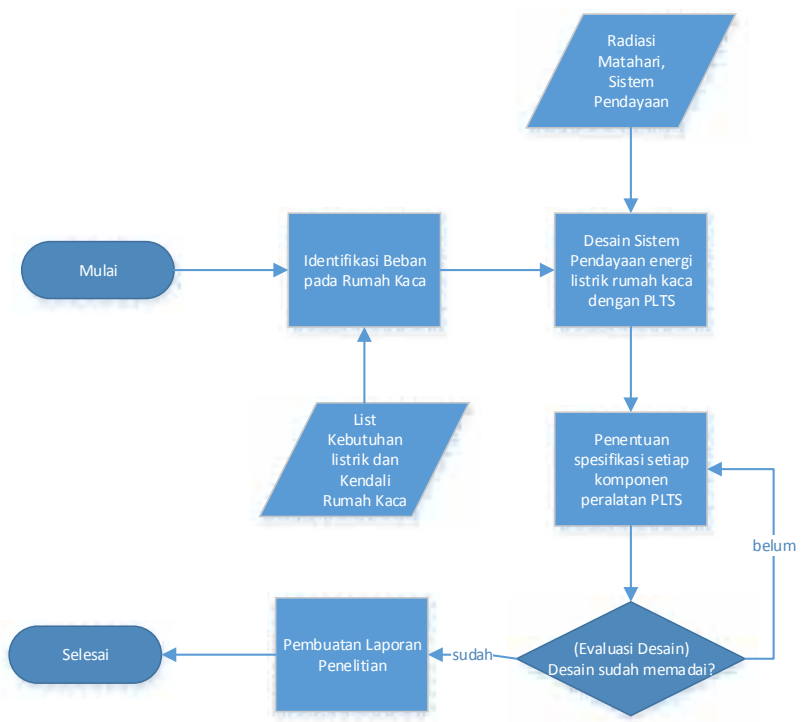

Gambar 1 Diagram Alir Metode Penelitan.

\subsection{Identifikasi Beban pada Rumah Kaca}

Rumah kaca yang akan diimplementasikan memiliki beban-beban tertentu karena merupakan salah satu rumah kaca smart dengan sistem kendali dan monitoring yang baik.

Oleh karena itu, beban-beban pada rumah kaca didayai dengan energi listrik. Berikut merupakan prototype skala kecil rumah kaca cerdas yang akan diimplementasikan secara nyata:

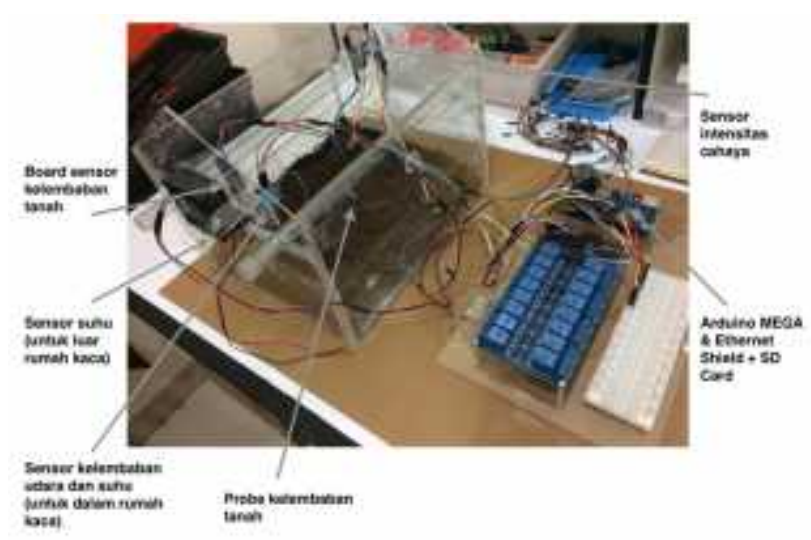

Gambar 2 Prototipe Rumah Kaca yang akan Diimplementasikan [1]

Berdasarkan dari prototype tersebut, akan diimplementasikan secara nyata untuk skala $2 \times 3 \mathrm{~m}^{2}$. Sehingga, daya yang dibutuhkan akan jauh lebih besar. Besarnya daya akan diukur dengan $\neg$ scaling dari prototype ini dan akan diukur dengan menggunakan wattmeter pada kemudian hari. Semua kebutuhan beban masih sangat tergantung pada implementasi dari pertanian rumah kaca itu sendiri, sehingga untuk saat ini, belum dapat ditentukan seberapa besar beban yang dibutuhkan.

\subsection{Desain Sistem Pendayaan Energi Listrik}

Analisis ini dilakukan untuk menentukan sistem pembangkit PV atau PLTS mana yang terbaik untuk pendayaan rumah kaca. Sebagai referensi, sistem energi listrik yang telah dilakukan pada [3] adalah sebagai berikut:

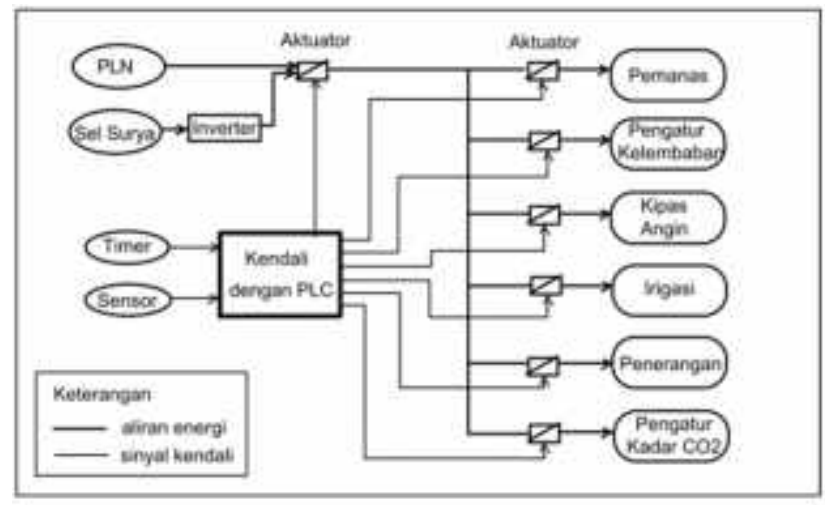

Gambar 3 Diagram Sistem Energi untuk Pertanian Rumah Kaca [3]

Diagram tersebut menjadi acuan sebagai sistem pembangkit PV untuk hybrid dimana sel surya disandingkan dengan sistem PLN. Akan tetapi, sistem energi listrik yang akan diimplementasikan diharapkan dapat secara mandiri atau stand-alone mendayai seluruh kebutuhan beban rumah kaca. 
Oleh karena itu, bila memungkinkan, akan dirancang sistem stand-alone untuk pendayaannya menjadi kurang lebih sebagai berikut:

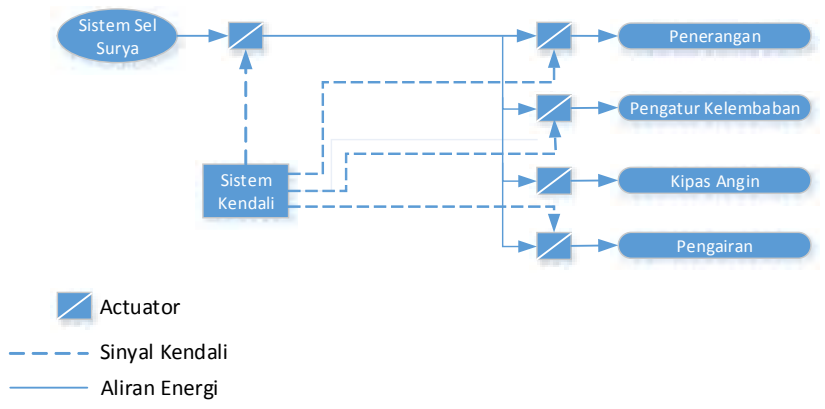

Gambar 4 Diagram Sistem Energi Implementasi Rumah Kaca

Desain sistem pendayaan energi listrik pada rumah kaca ini akan dilakukan berdasarkan analisis dan simulasi mengenai pembangkit PV itu sendiri. Seperti yang dibahas pada [10], dapat dirumuskan secara garis besar untuk desain sistem pendayaan dengan menggunakan sistem PV dengan aturan sebagai berikut:

1. Menentukan total arus beban dan jam operasional

2. Penambahan perhitungan losses

3. Menentukan intensitas cahaya harian equivalent sun hours (EHS)

4. Menentukan kebutuhan total arus solar array

5. Menentukan arrangement modul yang optimum untuk solar array

6. Menentukan besar baterai untuk reserve time rekomendasi

\subsection{Implementasi Nyata}

Implementasi nyata pada perancangan desain sistem pendayaan tersebut akan dilakukan. Oleh karena itu, dibutuhkan implementasi nyata rumah kaca tersebut juga. Implementasi pertanian rumah kaca cerdas akan dibuat di rooftop Universitas Katolik Parahyangan sebesar $2 \times 3 \mathrm{~m}^{2}$ dengan disandingkan dengan sel surya sebagai Pembangkit Listrik Tenaga Surya untuk mendayai sistem energi listrik yang ada pada rumah kaca tersebut.

Pada penelitian ini, diharapkan implementasi dapat dibuat sedemikian rupa agar daya yang dibutuhkan pada rumah kaca dapat terpenuhi seluruhnya sesuai waktu operasional yang dibutuhkan. Sehingga, implementasi dapat secara nyata dipakai pada kehidupan masyarakat nyata, dan membantu sektor pertanian untuk tetap bertahan di tengah kemajuan jaman ini.

\section{HASIL DAN PEMBAHASAN}

Penelitian ini menghasilkan sebuah sistem pendayaan energi listrik dengan memanfaatkan Pembangkit Listrik Tenaga Surya untuk mendayai kebutuhan beban listrik yang ada pada rumah kaca. Oleh karena itu, secara spesifik, hasil dari penelitian ini merupakan spesifikasi peralatan utama yang dibutuhkan agar sistem pendayaan energi listrik dengan PLTS tersebut dapat berjalan dengan baik.

\subsection{Konfigurasi Sistem Pendayaan Energi Listrik}

Untuk dapat mendayai suatu beban listrik dengan baik, dalam hal ini merupakan rumah kaca, diperlukan desain sistem yang baik pula. Oleh karena itu, konfigurasi komponen-komponen utama untuk PLTS sebagai sumber daya untuk beban pada rumah kaca tersebut perlu dijabarkan.

Sistem pendayaan energi listrik dengan Pembangkit Listrik Tenaga Surya (PLTS) off-grid tidak hanya sekedar membutuhkan modul panel surya saja, akan tetapi dibutuhkan komponenkomponen utama lainnya yaitu Solar Charge Controller (SCC), Inverter, dan Baterai.

Berikut merupakan skema konfigurasi sistem pendayaan tersebut:

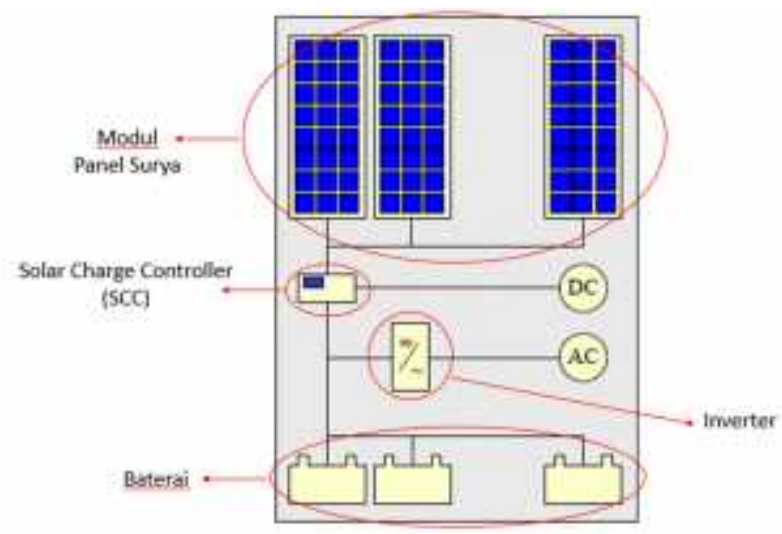

Gambar 5 Skema Sistem Pendayaan Energi Listrik dengan PLTS Off-Grid 


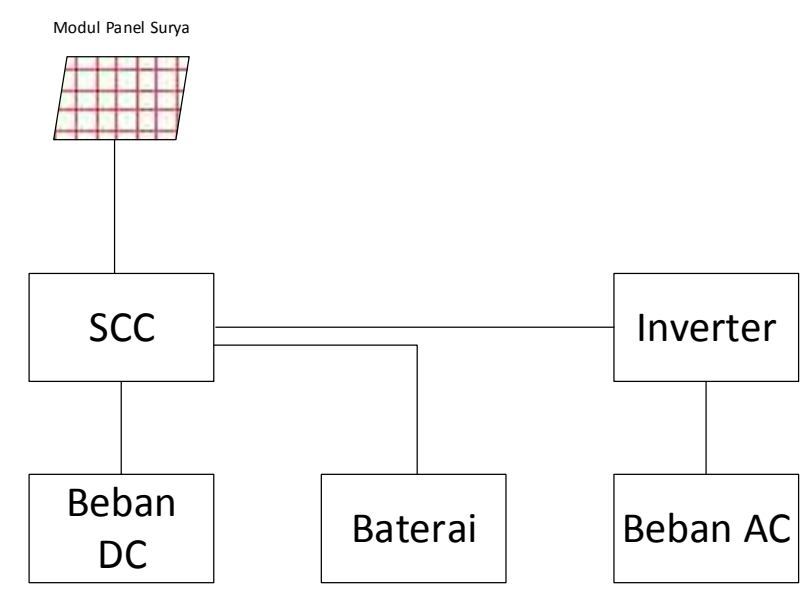

Gambar 6 Konfigurasi Sistem Pendayaan Energi Listrik dengan PLTS Off-Grid

Penentuan spesifikasi dari peralatan-peralatan utama untuk Solar Charge Controller, Baterai, Inverter, dan Modul Surya kemudian dilakukan untuk mendapatkan sistem pendayaan yang baik.

Penentuan spesifikasi tersebut dilakukan dengan menggunakan konsep backward engineering yang merupakan penemuan spesifikasi dari suatu perangkat dengan meninjau terlebih dahulu hasil yang terjadi (output) daripada sistem tersebut, kemudian analisis dilakukan mundur dari output menuju input ujung suatu sistem tersebut satu per satu.

Sehingga kemudian untuk desain sistem pendayaan energi listrik pada rumah kaca dengan memanfaatkan PLTS off-grid akan mengacu pada langkah-langkah berikut:

1. Identifikasi Beban

2. Pemilihan Modul Panel Surya

3. Penentuan Spesifikasi Inverter

4. Penentuan Spesifikasi Baterai

5. Penentuan Spesifikasi Solar Charge Controller

\subsection{Identifikasi Beban}

Rumah Kaca Cerdas direncanakan untuk dikonstruksi dengan ukuran $2 \times 3 \mathrm{~m}^{2}$, adapun beberapa beban yang dibutuhkan untuk rumah kaca tersebut. Beban terbesar yang terdapat pada sistem pengairan untuk tanaman pada rumah kaca yang membutuhkan pompa air. Pompa air tersebut menggunakan jenis aliran AC $220 \mathrm{~V}$ untuk dapat berjalan. Pompa air tersebut diperkirakan akan mempunyai kapasitas sebesar 150 Watt. Sedangkan untuk beban lainnya, seperti mikrokontroller, penghangat, dan lain-lain diasumsikan sangat kecil yaitu sekitar 3 Watt.

Perlu diketahui bahwa pompa air memiliki inrush current (arus yang ditarik oleh pompa pada saat pompa air starting) yang cukup besar dimana diasumsikan bahwa pada daya yang dibutuhkan untuk starting pompa tersebut sebesar 3 kali lebih besar dibandingkan kapasitas nominalnya, yaitu sebesar 450 Watt.

Pompa air akan melayani sistem pengairan rumah kaca secara berkala (tidak terus menerus) yang bergantung pada kelembaban tanah (akan dideteksi oleh sensor). Dalam keadaan worst case, pompa diasumsikan akan berjalan dalam waktu 1 jam per harinya dengan keadaan pompa menarik arus inrush current tersebut. Oleh karena itu, total beban dengan jam operasional 1 jam per harinya adalah 450 Watt-hour (Wh).

Sedangkan untuk beban lainnya, yang diasumsikan sebesar 3 Watt, akan melayani rumah kaca selama 24 jam. Sehingga, total beban dengan jam operasional 24 jam per harinya adalah $72 \mathrm{Wh}$.

Sehingga, dalam satu hari beban total untuk jam operasional 24 jam adalah $450 \mathrm{Wh}$ beban pompa ditambahkan dengan $72 \mathrm{Wh}$ beban lainnya yang menghasilkan beban total $522 \mathrm{Wh}$.

Tabel 1 Identifikasi Beban Rumah Kaca

\begin{tabular}{|c|c|c|c|c|}
\hline Beban & $\begin{array}{c}\text { Jenis } \\
\text { Aliran } \\
\text { Listrik }\end{array}$ & $\begin{array}{c}\text { Kapasitas } \\
\text { Beban } \\
\text { (Watt) }\end{array}$ & $\begin{array}{c}\text { Jam } \\
\text { Operasional/hari }\end{array}$ & $\begin{array}{c}\text { Total } \\
\text { Beban } \\
\text { (Wh) }\end{array}$ \\
\hline $\begin{array}{c}\text { Pompa untuk } \\
\text { Pengairan }\end{array}$ & $\begin{array}{c}\text { AC } \\
220 \mathrm{~V}\end{array}$ & 450 & $1 \mathrm{jam}$ & 450 \\
\hline $\begin{array}{c}\text { Beban } \\
\text { Mikrokontroler, } \\
\text { dll }\end{array}$ & DC/AC & 3 & 24 jam & 72 \\
\hline \multicolumn{4}{|c|}{ Total } & 522 \\
\hline
\end{tabular}

\subsection{Pemilihan Modul Panel Surya}

Berdasarkan data yang didapatkan, rata-rata radiasi sinar matahari di Bandung berkisar antara 4.5 $-6.3 \mathrm{kWh} / \mathrm{m}^{2} /$ hari.

Dengan melihat beban sebesar $522 \mathrm{Wh}$ yang dihitung sebelumnya, besar dari modul panel surya kemudian dapat dipilih dengan menggunakan rumus:

$$
M \quad S=\frac{B \quad T}{R \quad M \quad h a}
$$

Oleh karena itu, dengan mengambil asumsi radiasi sinar matahari terkecil $\left(4.5 \mathrm{kWh} / \mathrm{m}^{2} /\right.$ hari. Sehingga didapatkan angka besar modul 116. Angka tersebut kemudian dijadikan acuan dalam pemilihan modul panel surya.

Modul panel surya yang terdapat di lapangan adalah $100 \mathrm{Wp}, 120 \mathrm{Wp}, 150 \mathrm{Wp}, 200 \mathrm{Wp}$. Kemudian dipilih angka yang mendekati hasil perhitungan tersebut. Sehingga dipilih Modul Surya dengan kapasitas $120 \mathrm{Wp}$.

Modul Surya dengan kapasitas 120 Wp tersebut dapat menghasilkan sebesar 120 Watt pada 
RESISTOR (elektRonika kEndali telekomunikaSI tenaga liSTrik kOmputeR) Vol. 2 No. 1 e-ISSN : 2621-9700, p-ISSN : 2654-2684

saat puncak harian berdasarkan data radiasi sinar matahari di Bandung yang didapatkan.

\subsection{Penentuan Spesifikasi Inverter}

Inverter adalah suatu perangkat elektronika pengubah listrik arus searah menjadi listrik arus bolak-balik pada tegangan dan frekuensi yang dapat diatur, atau dipergunakan untuk mengubah tegangan DC (Direct Current) menjadi tegangan AC (Alternating Curent).

Untuk dapat menentukan spesifikasi dari inverter, dalam hal ini adalah kapasitas daripada inverter tersebut, perlu ditinjau beban yang mungkin terjadi dalam sistem pendayaan energi listrik untuk rumah kaca ini dalam satu waktu.

Seperti yang telah dibahas sebelumnya, beban terbesar pada sistem rumah kaca adalah pompa air yang menarik daya paling besar pada saat starting, yaitu sebesar 450 Watt. Beban lainnya, yang diasumsikan kecil, bernilai 3 Watt. Oleh karena itu, total beban yang dapat terjadi dalam satu waktu adalah sebesar 453 Watt.

Sehingga, dengan meninjau kapasitas yang tersedia di pasaran, kapasitas inverter yang dipilih adalah 500 Watt dengan jenis pure-sine wave inverter. Pemilihan pure-sine adalah dengan pertimbangan umur atau keawetan daripada pompa air yang merupakan beban terbesar di rumah kaca tersebut.

\subsection{Penentuan Spesifikasi Baterai}

Baterai pada sistem pendayaan energi listrik untuk rumah kaca berguna untuk menjaga suplai daya ke beban yang ada pada saat modul surya tidak dapat menghasilkan daya (mendung, malam, ataupun karena keadaan lainnya).

Penentuan spesifikasi baterai dilakukan dengan meninjau beberapa parameter berikut:

- Beban (522 Wh)

- Autonomous Day dipilih 1.5 (dapat menyuplai dalam keadaan tanpa radiasi matahari sebanyak 1.5 hari)

- Depth of Discharge (\%)

- Merupakan kedalaman discharge baterai (dipilih $70 \%$ ), atau baterai dijaga agar selalu tersisa sebesar $30 \%$

- Depth of Discharge atau DOD akan berpengaruh terhadap umur baterai. Hal ini perlu diperhatikan karena baterai merupakan komponen termahal pada sistem PLTS off-grid.

- Semakin kecil pemilihan DOD, baterai akan lebih awet.

- Tegangan Sistem

- dipilih tegangan yang umum digunakan $(12 \mathrm{kV})$
Dengan meninjau beberapa parameter tersebut, kapasitas baterai dipilih dengan menggunakan perhitungan:

$$
\text { Ki } \quad=\frac{B \quad \times A 1}{D \times T}
$$

Perhitungan tersebut akan menghasilkan kapasitas baterai dalam satuah Ampere-hour (Ah). Dengan memasukan angka yang telah dijabarkan sebelumnya, perhitungan tersebut menghasilkan kapasitas baterai sebesar 93.21 Ah.

Dengan meninjau kapasitas baterai yang ada di pasaran, dipilih baterai dengan kapasitas $100 \mathrm{Ah}$ dengan tegangan $12 \mathrm{~V}$. Baterai yang dipilih adalah jenis VRLA-GEL yang efektif untuk DOD sebesar $70 \%$.

\subsection{Penentuan Spesifikasi Solar Charge Controller}

Solar Charge Controller (SCC) untuk sistem pendayaan energi listrik PLTS off-grid ini merupakan alat untuk mengatur agar sistem pendayaan yang telah dijelaskan sebelumnya bekerja dengan baik.

SCC ini akan mengatur beberapa hal berikut:

- Sistem charging dan discharging baterai

- Maximum power point tracking (dari modul surya)

- Keluaran beban DC

- Keluaran beban AC

Pada penelitian ini, SCC merupakan black box yang langsung ada di pasaran dan tidak diketahui bagian kontrol daripada SCC tersebut. Sehingga spesfikasi yang dibutuhkan hanya berupa kapasitas arus, yaitu sebesar $20 \mathrm{~A}$.

Penentuan spesifikasi tersebut adalah dengan meninjau kapasitas dari modul surya yang dipilih dengan tegangan DC dari sistem pendayaan energi listrik yang dibuat. Modul surya dengan kapasitas $120 \mathrm{Wp}$, dengan tegangan $12 \mathrm{~V}$, akan menghasilkan arus sebesar 10 Ampere. Di pasaran, kapasitas SCC yang tersedia adalah $10 \mathrm{~A}, 20 \mathrm{~A}$, dan $30 \mathrm{~A}$. Dengan pertimbangan keamanan, dipilih 20 A untuk kapasitas arus dari SCC tersebut.

\subsection{Implementasi Sistem Pendayaan}

Implementasi secara nyata akan dilakukan untuk mendayai sebuah rumah kaca dengan beban yang telah diidentifikasi sebelumnya. Oleh karena itu, pengadaan dari peralatan-peralatan hasil dari perhitungan tersebut dilakukan.

Berikut merupakan hasil dokumentasi dari setiap peralatan-peralatan utama yang telah dipilih sebelumnya hasil dari desain sistem untuk kemudian diimplementasikan pada rumah kaca sesungguhnya: 
RESISTOR (elektRonika kEndali telekomunikaSI tenaga liSTrik kOmputeR) Vol. 2 No. 1 e-ISSN : 2621-9700, p-ISSN : 2654-2684

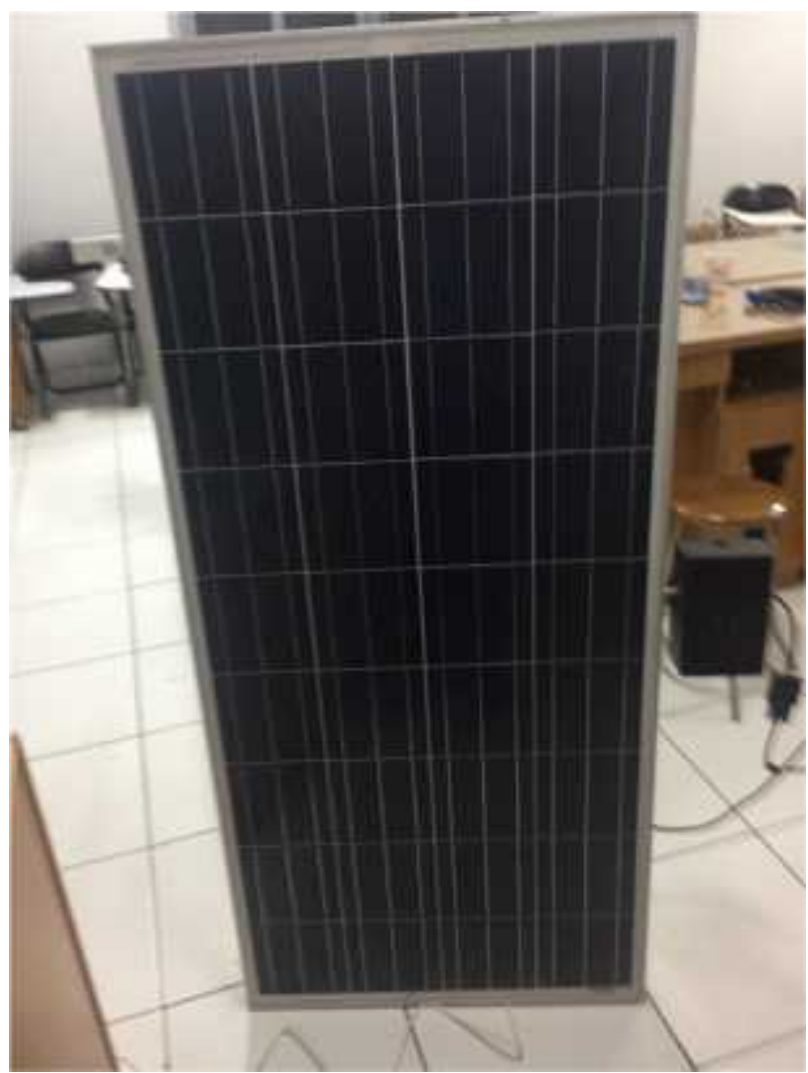

Gambar 7 Modul Panel Surya 120 Wp

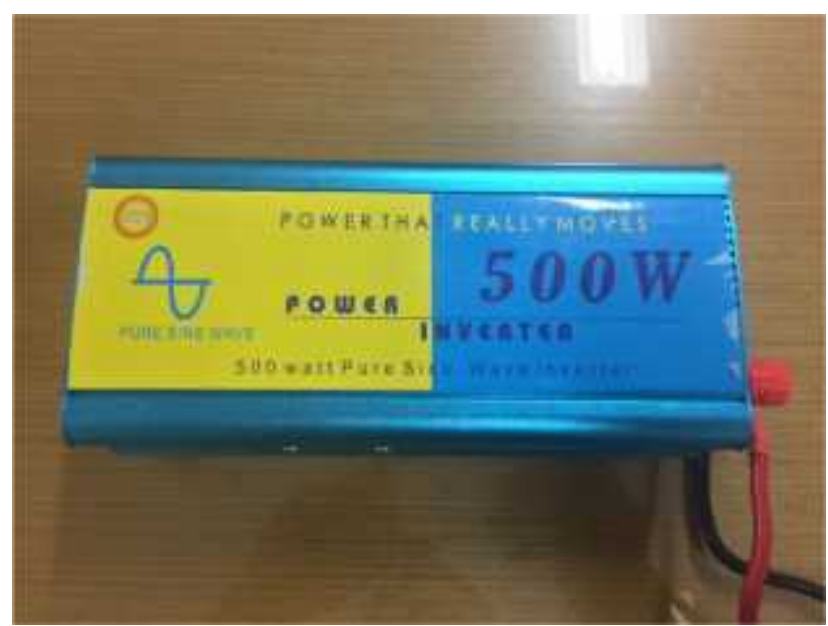

Gambar 8 Inverter Pure Sine-Wave 500 W

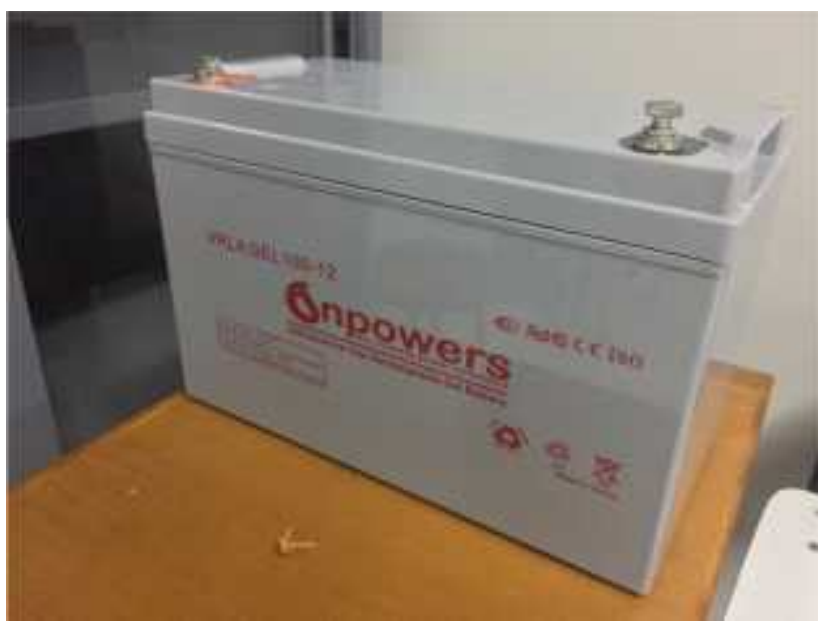

Gambar 9 Baterai VRLA-GEL 100 Ah 12 V

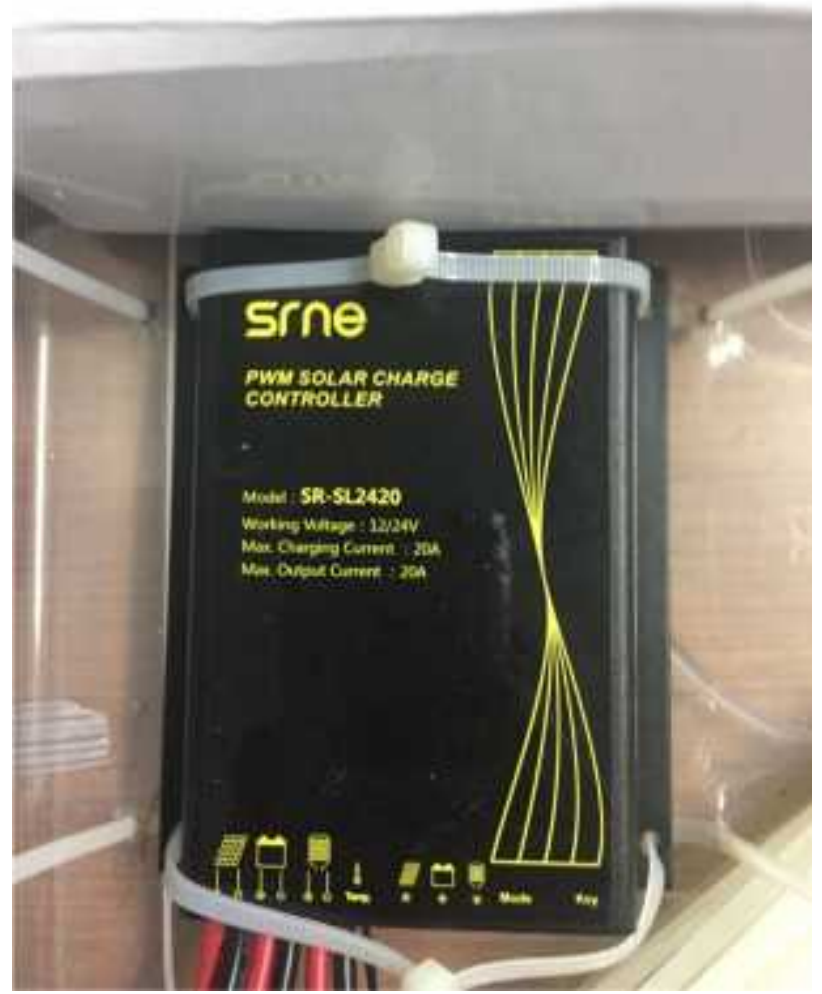

Gambar 10 Solar Charge Controller 20 A

\section{KESIMPULAN}

Berdasarkan penelitian yang dilakukan, dapat disimpulkan bahwa:

1. Desain sistem pendayaan listrik untuk rumah kaca dengan PLTS untuk rumah kaca dilakukan dan menghasilkan beberapa spesifikasi peralatan utama untuk sistem PLTS off-grid seperti:

a. Modul Panel Surya

b. Inverter

c. Baterai

d. Solar Charge Controller 
2. Dalam satu hari beban total untuk jam operasional 24 jam adalah $450 \mathrm{Wh}$ beban pompa (asumsi beroperasi 1 jam per hari) ditambahkan dengan 72 Wh (asumsi beroperasi 24 jam satu hari) beban lainnya yang menghasilkan beban total $522 \mathrm{Wh}$.

3. Modul Panel Surya yang dipilih, berdasarkan perhitungan, adalah $120 \mathrm{Wp}$.

4. Kapasitas inverter yang dipilih adalah 500 Watt dengan jenis pure-sine wave inverter.

5. Berdasarkan perhitungan, spesifikasi baterai yang dipilih adalah baterai dengan kapasitas 100 Ah dengan tegangan $12 \mathrm{~V}$. Baterai yang dipilih adalah jenis VRLA-GEL yang efektif untuk DOD sebesar $70 \%$.

6. Spesifikasi Solar Charge Controller yang dipilih adalah Solar Charge Controller dengan kapasitas arus $20 \mathrm{~A}$.

Selain itu, terdapat beberapa saran sebagai berikut:

1. Desain sistem pendayaan energi listrik untuk rumah kaca dengan menggunakan PLTS sebaiknya tidak hanya berdasarkan perhitungan, tetapi didasarkan juga pada simulasi.

2. Sebaiknya dilakukan instalasi dengan sistem sederhana sehingga dapat dilihat apakah sistem telah berjalan dengan benar atau tidak

3. Dilakukan penentuan spesifikasi cabling dengan meninjau konfigurasi, jarak panel surya ke beban, dan keadaan lapangan lainnya.

\section{DAFTAR PUSTAKA}

[1] C. F. Naa, E. Padang, and Y. S. Handayani, "Sistem Monitoring dan Kontrol Rumah Kaca berbasis Arduino, LabView dan Antarmuka Web," pp. 2-9, 2015.

[2] S. Munir, "Rancangan Smart Greenhouse dengan Teknologi Mobile untuk Efisiensi Tenaga, Biaya, dan Waktu dalam Pengelolaan Tanaman," 2010.

[3] A. Sugiyono, "Kendali Sistem Energi untuk Pertanian Rumah Kaca,” pp. 1-4, 1998.

[4] Y. S. Defriyadi, "Pengendali Intensitas cahaya, Suhu, dan Kelembapan pada Rumah Kaca dengan Metode PID," Bengkulu, 2014.

[5] B. A. Pamungkas, A. F. Rochim, and E. D. Widianto, "Perancangan Jaringan Sensor Terdistribusi untuk Pengaturan Suhu, Kelembaban, dan Intensitas Cahaya," vol. 1, no. 2, pp. 42-48, 2013.
[6] Y. R. Dumal and J. S. Chitode, "Greenhouse Automation using Zigbee and Smartphone," International Journal of Advanced Research in Green House Automation using Zigbee and Smart Phone, vol. 3, no. 5, pp. 495-501, 2013.

[7] The Sierra Club, "Clean Energy Solutions Renewable Energy," 2010.

[8] F. Horch, "Climate Solutions Summit," no. April, 2013.

[9] M. Diesendorf, "Greenhouse Solutions with Sustainable Energy," no. December, p. 40, 2007.

[10] M. Zeman, "Photovoltaic Systems," in Solar Cells, Delft University of Technology, 2012. 
RESISTOR (elektRonika kEndali telekomunikaSI tenaga liSTrik kOmputeR) Vol. 2 No. 1 e-ISSN : 2621-9700, p-ISSN : 2654-2684 